University of Nebraska - Lincoln DigitalCommons@University of Nebraska - Lincoln

USDA National Wildlife Research Center - Staff U.S. Department of Agriculture: Animal and Plant Publications Health Inspection Service

2014

\title{
Coqui frog populations are negatively affected by canopy opening but not detritus deposition following an experimental hurricane in a tropical rainforest
}

Paul D. Klawinski

William Jewell College, klawinskip@william.jewell.edu

Ben Dalton

William Jewell College

Aaron B. Shiels

University of Puerto Rico-Rio Piedras, Aaron.B.Shiels@aphis.usda.gov

Follow this and additional works at: https://digitalcommons.unl.edu/icwdm_usdanwrc

Part of the Life Sciences Commons

Klawinski, Paul D.; Dalton, Ben; and Shiels, Aaron B., "Coqui frog populations are negatively affected by canopy opening but not detritus deposition following an experimental hurricane in a tropical rainforest" (2014). USDA National Wildlife Research Center - Staff Publications. 1538.

https://digitalcommons.unl.edu/icwdm_usdanwrc/1538

This Article is brought to you for free and open access by the U.S. Department of Agriculture: Animal and Plant Health Inspection Service at DigitalCommons@University of Nebraska - Lincoln. It has been accepted for inclusion in USDA National Wildlife Research Center - Staff Publications by an authorized administrator of DigitalCommons@University of Nebraska - Lincoln. 


\title{
Coqui frog populations are negatively affected by canopy opening but not detritus deposition following an experimental hurricane in a tropical rainforest
}

\author{
Paul D. Klawinski ${ }^{\mathrm{a}, *}$, Ben Dalton ${ }^{\mathrm{a}, 1}$, Aaron B. Shiels ${ }^{\mathrm{b}, 2}$ \\ ${ }^{a}$ Department of Biology, William Jewell College, 500 College Hill, WJC Box 1040, Liberty, MO 64068-1896, USA \\ ' Institute for Tropical Ecosystems Studies, University of Puerto Rico-Rio Piedras, P.O. Box 70377, San Juan, PR 00936-8377, USA
}

\section{A R T I C L E I N F O}

\section{Article history:}

Available online 17 April 2014

\section{Keywords}

Detritus addition

Eleutherodactylus coqui

Forest canopy gap

Frog density dynamics

Hurricane disturbance

Tropical rainforest windstorm

\begin{abstract}
A B S T R A C T
Hurricanes, cyclones, and typhoons are common disturbances in many island and coastal forests. There is a lack of understanding of the importance to forest biota of the two major physical aspects that occur simultaneously during a hurricane: canopy disturbance and detritus (debris) deposition onto the ground. Using a replicated factorial design, our study involved experimentally determining the independent and interactive effects of canopy opening and debris additions to the forest floor on densities of coqui frogs (Eleutherodactylus coqui). Coquies are the dominant amphibian, and second most common vertebrate species, in the Luquillo Experimental Forest (LEF), a montane, tropical rainforest in northeastern Puerto Rico that frequently experiences hurricanes. Frogs were sampled in all twelve $30 \times 30 \mathrm{~m}$ plots at three periods prior to installing treatments (July 2003, January 2004, July 2004), and at months $1,3,6$, and 12 post-treatment. The degree of canopy opening and amount of debris deposited onto the forest floor by our experimental treatments closely mimicked conditions resulting from Hurricane Hugo, a severe hurricane that passed over the LEF in 1989. Based on findings from past studies involving natural hurricanes in the LEF, we predicted that coqui densities would increase in response to debris additions, and decrease or remain unchanged in response to canopy disturbance. However, we found that debris deposition had no significant effect on coqui density and that the opening of the canopy was the dominant aspect affecting coqui by significantly reducing their densities. We identified several possible explanations for the decreased coqui densities in open-canopy plots, including decreased litter moisture and insect prey, and temporal and spatial scales associated with disturbance that may have influenced coqui behavior. Following natural hurricanes, and in light of our findings from experimental hurricane impacts, we expect that coquies benefit from patches of intact canopy while suffering reduced densities in opencanopy settings. Furthermore, based on our study and other experimental forest studies involving frogs, future forest practices that remove significant canopy should probably be viewed as having an initially (up to 1 year) negative effect on the frog community.
\end{abstract}

(c) 2014 Elsevier B.V. All rights reserved.

\section{Introduction}

Hurricanes are among the most common large-scale disturbances in tropical forests (Lugo et al., 1983; Everham and Brokaw, 1996; Whitmore and Burslem, 1998; Lugo, 2008); they simultaneously create canopy gaps within predominately

\footnotetext{
* Corresponding author. Tel.: +1 8164157628; fax: +1 8164155024.

E-mail address: klawinskip@william.jewell.edu (P.D. Klawinski).

1 Present address: Department of Biology, Missouri State University, Springfield, MO 65897-0095, USA.

2 Present address: USDA, National Wildlife Research Center, Hawaii Field Station, P.O. Box 10880, Hilo, HI 96721 USA.
}

closed-canopy forests while adding large amounts of fresh, non-senesced biomass to the forest floor (Turton, 1992; Ostertag et al., 2003). While the dynamics of hurricane disturbance in tropical forests have been studied from the perspective of plant and animal community responses (Waide, 1991; Burslem et al., 2000; Angulo-Sandoval et al., 2004), no studies have attempted to decouple the effects of canopy opening and the concomitant changes in microclimate (e.g., light availability, temperature variation, drying and wetting cycles) from the effects of biomass addition (e.g., increased nutrient availability and energy to detrital food webs, increased forest floor structure). Such experimental decoupling of such prominent factors that occur simultaneously during a 
hurricane will help inform ecologists and forest managers about the mechanisms of forest change following large windstorms such as hurricanes.

Studies of amphibian population dynamics after canopy disturbance due to windstorms are relatively uncommon (but see Woolbright, 1991, 1996; Greenberg, 2001; Vilella and Fogarty, 2005), with most amphibian studies focused on the effects of canopy disturbance due to human land use (e.g., timber extraction activities; see Ash, 1988; Horn et al., 2005; Ernst and Rödel, 2005; Ernst et al., 2006; Popescu et al., 2012). The responses of amphibian species to canopy disturbance have ranged from populations increasing in abundance (Woolbright, 1991, 1996; Horn et al., 2005; Popescu et al., 2012), decreasing in abundance (Pough et al., 1987; Petranka et al., 1993; Popescu et al., 2012) or exhibiting no change (Greenberg, 2001; Vilella and Fogarty, 2005). The underlying drivers of these amphibian responses to canopy disturbance have been attributed to changes in microclimate (Pough et al., 1987; Woolbright, 1996; Popescu et al., 2012), prey availability (Horn et al., 2005), predator abundance (Woolbright, 1991, 1996), and habitat structure (Woolbright, 1991, 1996).

Most of the studies listed above were conducted in temperate regions where the focal amphibian group was Caudata (salamanders, broadly defined) and the type of disturbance was human land use related to timber extraction (Pough et al., 1987; Ash, 1988; Harpole and Haas, 1999; Petranka et al., 1993). Fewer studies concentrate on Anurans (frogs and toads) and/or natural canopy disturbances in tropical forests (Gardner et al., 2007; but see Woolbright, 1991, 1996; Vilella and Fogarty, 2005). In the Appalachian Mountains of North Carolina, U.S., Greenberg (2001) compared amphibian and reptile communities in undisturbed hardwood-dominated forest to those in forest gaps created by hurricane disturbance and found that lizard and snake species richness and abundance increased in gaps relative to the undisturbed forest. However, there were no differences between gaps and controls for amphibian species richness or in any measure of abundance, which Greenberg (2001) attributed to pre-adaptations of the amphibians to xeric conditions of the forest gaps. Also in a hardwood forest in the Southeastern U.S., the green tree frog (Hyla cinerea) abundance increased after formation of artificial gaps created by timber extraction, and such increases were positively correlated with insect abundance (Horn et al., 2005).

In Puerto Rico, the two vertebrate groups that numerically dominate most forests are lizards in the genus Anolis (family Polychrotidae) and tree frogs in the genus Eleutherodactylus (family Leptodactylidae). In the Luquillo Experimental Forest (LEF) of northeastern Puerto Rico, Eleutherodactylus coqui (hereafter, referred to as coqui or coquies (pl.)) has been estimated to reach densities of 20,570 frogs ha $^{-1}$ (Stewart and Woolbright, 1996) while anoles (Anolis gundlachi, A. stratulus and A. evermanni) reach combined densities of 29,370 lizard ha ${ }^{-1}$ (Reagan, 1996). Because of their overall abundance, the dynamics of coqui populations have been the subject of many studies since 1980 .

Coqui population size in the LEF increased following concomitant increases in forest floor structure (Stewart and Pough, 1983). In the same forest, Woolbright (1991) found that coqui populations increased 4-fold at 1 year after Hurricane Hugo. Such increases in coqui abundances were attributed to a variety of contributing factors, including increases in forest floor habitat structure that benefited coqui egg-laying and males guarding the egg masses (see Stewart and Pough, 1983), increases in forest floor humidity due to the emergence of dense understory vegetation, and the reduction of major invertebrate predators that probably competed for resources with coqui and served as potential predators of coquies (Formanowicz et al., 1983; Woolbright, 1991, 1996). Additionally, coqui abundances can shift dramatically due to relatively high fecundity, and reproduction can occur up to 9 times per year with clutches of 15-45 eggs (Rivero, 1978). Despite such high fecundity from frequent reproductive events, an increase in the adult coqui population was not detectable until 1 year after a severe hurricane (Hugo) passed over the LEF (Woolbright, 1991, 1996). Woolbright (1991) suggested low juvenile survivorship due to desiccation in the leaf litter as a possible explanation for the observed time lag in coqui population increase following the passing of Hurricane Hugo in 1989. Moreover, there was a pronounced drought that lasted nearly 3 months in the LEF immediately following the passage of Hurricane Hugo (Scatena and Larsen, 1991; Woolbright, 1991). Woolbright (1996), studying the same plot in the LEF, examined pre-Hurricane Hugo coqui population dynamics and found that in response to tree fall gaps that occurred in January 1988, the coqui population increased similarly to that after Hurricane Hugo but at an accelerated pace ( 5 months). In contrast, Vilella and Fogarty (2005) reported no changes in coqui populations at two sites in the western Cordillera Central of Puerto Rico following the passing of Hurricane Georges in 1998, but this lack of population change may have been due to their sampling occurring just 8 months following the storm.

Given the conflicting results from studies examining frog population dynamics following natural canopy disturbances and the variety of explanations for those dynamics, experiments designed to examine the underlying mechanisms affecting frog population fluctuations would be informative. Canopy disturbance and debris deposition to the forest floor are the two major physical aspects that occur simultaneously during a hurricane. In all previous studies of the response of coqui populations to hurricane disturbances, it has been impossible to separate the independent effects of canopy opening and concomitant changes in microclimate, from the deposition of canopy debris that alters microhabitat structure, humidity at the forest floor and/or nutrients and energy availability. In 2004, we implemented an experiment to separate the effects of these two major aspects of hurricane disturbance (canopy openness and debris deposition) on coqui populations. We tested the following hypotheses posed by Stewart and Pough (1983) and Woolbright (1991, 1996): (1) coquies are limited by the availability of understory nest sites, (2) nest site limitation is relieved by the addition of leaf litter to the forest floor, and (3) leaf litter compensation for nest site limitation will be independent of any microclimate changes that occurs as a result of canopy opening. We predict that coqui densities will increase in response to debris additions, and decrease or remain unchanged in response to canopy disturbance.

\section{Methods}

\subsection{Study site}

This study took place in the LEF of Puerto Rico, Western Atlantic, near the El Verde Field Station (EVFS; $18^{\circ} 20^{\prime} \mathrm{N}, 65^{\circ} 49^{\prime} \mathrm{W}$; see map in Shiels and González, 2014). The LEF is a 11,000 ha tropical $\left(18^{\circ} \mathrm{N}\right.$ latitude) evergreen forest that spans elevations of approximately $100-1075 \mathrm{~m}$. Mean annual rainfall at EVFS is $3500 \mathrm{~mm}$, and monthly precipitation is variable, but May to December are usually the wettest months and January to April are typically slightly drier (Zimmerman et al., 2007). The study site is in tabonuco forest (subtropical wet forest in the Holdridge System; Ewel and Whitmore, 1973), which is the lowermost and dominant of four general vegetation zones along an altitudinal gradient across the LEF. The most common trees at the study site are Dacryodes excelsa (Burseraceae), Prestoea acuminata var. montana (syn. Prestoea montana; Arecaceae), Sloanea berteriana (Elaeocarpaceaea), and Manilkara bidentata (Sapotaceae). In 2003, prior to our treatments, the 135 tallest canopy trees at our study site averaged $18.1 \pm 0.3 \mathrm{~m}$ (range: 13-30 m; A. Shiels, unpublished data). 


\subsection{Experimental design}

The Canopy Trimming Experiment (CTE) followed a 2-factor, randomized block design with canopy trimming and debris addition as the main effects (both fixed effects). Each of three blocks (A, B and C) were established in tabonuco forest with similar land-use history, soils, slope, and elevation (340-485 $\mathrm{m}$ a.s.l.) in an area of approximately 50 ha near EVFS (see Shiels et al., 2010 for details). In each block, four $30 \times 30 \mathrm{~m}$ plots were established (12 plots total). Plot size was chosen after considering the apparent patchiness of damage to forest canopies in the LEF following Hurricane Hugo (Brokaw and Grear, 1991), and plots within blocks were located at least $20 \mathrm{~m}$ distant from the edge of adjacent plots. To minimize edge effects, a $20 \times 20 \mathrm{~m}$ interior measurement area was established in each $30 \times 30 \mathrm{~m}$ plot. The $20 \times 20 \mathrm{~m}$ measurement area was divided into a grid of 16 quadrats (each c. $4.7 \times 4.7 \mathrm{~m}$ ), and walking trails were established between adjacent quadrats to minimize disturbance.

Each plot within a block was randomly assigned one of the four treatments: (1) Trim + Debris, which most closely simulated conditions of a natural hurricane, and where the canopy was trimmed and detritus from the trimming was added to forest floor; (2) Trim + No Debris, where the canopy was trimmed and the detritus from the trimming was removed and added to the No Trim + Debris plot; (3) No Trim + Debris, where the canopy was unaltered, but detritus from the Trim + No Debris plot was added to the forest floor; (4) No Trim + No Debris, where neither the canopy nor the detritus were altered, thus serving as the Control. Each of the blocks was treated individually and was completed before beginning treatments on a subsequent block. Treatment application extended from October 2004 until June 2005. The area trimmed included the vertical projection of the $30 \times 30 \mathrm{~m}$ plot, utilizing the following methods: All non-palm trees $\geqslant 15 \mathrm{~cm}$ diameter at $1.3 \mathrm{~m}$ height (d.b.h.) within the $30 \times 30 \mathrm{~m}$ area had their branches that were less than $10 \mathrm{~cm}$ diameter removed. For non-palm trees between 10 and $15 \mathrm{~cm}$ d.b.h., each tree was trimmed at $3 \mathrm{~m}$ height. For palms $\geqslant 3 \mathrm{~m}$ tall (at the highest part of the leaf above ground), fronds were trimmed at the connection with the main stem and the apical meristem was preserved. Therefore, except for some palms that had fronds attached to their stem below $3 \mathrm{~m}$ height, no vegetation of any type was trimmed below $3 \mathrm{~m}$ height. The trimmed debris was sorted into three categories: wood (branches $\geqslant 1.5 \mathrm{~cm}$ diameter), leaves and twigs (branches $<1.5 \mathrm{~cm}$ diameter and all non-palm foliar material), and palm fronds. All debris was then piled by category outside respective treatment plots until trimming was completed within a block. Debris was added to plots by spreading it evenly across each $30 \times 30 \mathrm{~m}$ area. This was done in order to minimize heterogeneity of debris additions within plots. All debris addition plots within a block had equal portions of debris added. Similarly, the amounts of each category of debris $(\mathrm{kg})$ added to treatments among blocks were matched as closely as possible. In total, the amount of debris added to each of the six detritus addition plots was $5408 \pm 143 \mathrm{~kg}$ (dry-mass basis; or $6 \mathrm{~kg} \mathrm{~m}^{-2}$ ), represented by $67 \%$ wood, 29\% leaves and twigs, and $4 \%$ palm fronds (Shiels et al., 2010). On average, it took 75 days to complete all treatments within a block. Because of the length of time required to complete the trimming and debris addition to each block, block B was completed in the dry season (January to April) while block A was completed in the wet season (June to December). Block C was completed at the end of the wet season (March). Wet and dry seasons in the LEF are comparative terms based on long-term average rainfall (see Fig. 1.5 in Waide and Reagan, 1996). The average mortality of trimmed trees was $5.3 \%$, and the number of stems $\geqslant 1 \mathrm{~cm}$ d.b.h. doubled in the Trim plots after 2 years (Shiels et al., 2010).

\subsection{Frog population surveys}

Frogs were sampled in all plots at three periods prior to installing treatments (July 2003, January 2004, July 2004), and at 2 month intervals for 1 year post-treatment. Frogs were sampled using line transects in the three internal trails within each plot in order to reduce the amount of disturbance in plots being utilized by other researchers. Transects were sampled between $1900 \mathrm{~h}$ and $0200 \mathrm{~h}$ as frog activity begins to decline after $0200 \mathrm{~h}$ (Woolbright, 1991). All vegetation, dead wood, rocks and leaf litter $2.5 \mathrm{~m}$ to either side of the trail was visually searched using a headlamp (Woolbright, 1991, 1996). Total nightly coqui movement averages $3.0-4.5 \mathrm{~m}$ and does not differ between sexes (Woolbright, 1985), which gives us confidence that our search and sampling methodology was robust for this forest. Frogs were identified, classified as adults or juveniles (based on a lower limit to adult size of $2.5 \mathrm{~cm}$ ) and sexed when possible. The distance from the transect to each frog was measured using a laser distance meter (Leica DistoLite5 or Leica 56DISTM) so that a detection function could be constructed for each plot and census for use in determining densities using the shaped restricted line transect method (Krebs, 1999). Because we were limited to sampling along walking trails within the plots, the shaperestricted line transect methodology (Krebs, 1999) was favored over mark and recapture methodology to estimate frog density. Estimates of frog density for each transect within each plot ( $n=3$ transects per plot) within each block were analyzed using a 2-way, randomized block design (data fit parametric assumptions) with each transect within a plot representing repeated measures of frog density (General Linear Model specified for a 2-way analysis of variance (ANOVA), randomized block design with repeated measures in Statistica, version 10 (StatSoft, 2011)). In total, one such ANOVA was conducted on the pretreatment data (years 2003-2004), and a separate ANOVA was conducted on all post-treatment data.

\section{Results}

During our study period, we made 7968 observations of coquies, of which 7093 (89\%) were juveniles, 560 (7\%) were adult males and 315 (4\%) were adult females. A repeated measures ANOVA conducted on the pretreatment data showed no significant effects for plots planned for canopy trimming or debris addition $\left(F_{1,30}=0.69\right.$, $p=0.4143 ; F_{1,30}=0.02, p=0.8761$, respectively), no significant differences among blocks, and no significant interactions; however, time was a significant factor when pretreatment data were analyzed (Fig. 1). After experimental treatments were installed, significant block effects existed $\left(F_{2,30}=25.34 ; p<0.0001\right.$; Fig. 2$)$. Coqui densities were negatively affected by canopy trimming (i.e., in Trim + Debris, and Trim + No Debris) relative to intact canopy plots (No Trim + No Debris, and No Trim + Debris $)\left(F_{1,30}=20.83 ; p<0.0001\right.$; Fig. 1$)$, but detritus addition had no significant effect $\left(F_{1,30}=0.26\right.$; $p=0.6114$; Fig. 1). Even though the treatments began during different seasons (staggered by block), the experimental treatment effects apparently overwhelmed any seasonal differences (Fig. 1) that were present. We found significant interactions affecting frog densities that included time since treatment and canopy trimming $\left(F_{6,180}=3.83 ; p=0.0013 ;\right.$ Fig. 1$)$, and time since manipulation and block $\left(F_{12,180}=11.81 ; p<0.0001\right.$; Fig. 2$)$, which presumably reflected the effects of beginning the different blocks at different seasons. There were no further significant differences in our study.

\section{Discussion}

We expected that coqui densities in the Canopy Trimming Experiment would rank in the following treatment order: No Trim + Debris $>$ Trim + Debris $>$ No Trim + No Debris $>$ Trim + No 


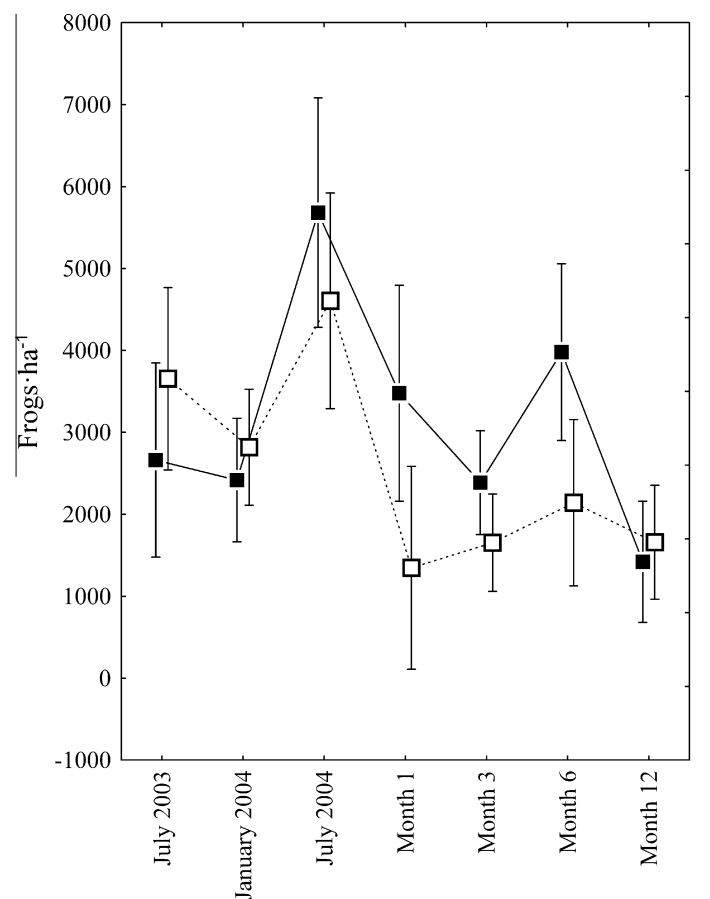

No Debris

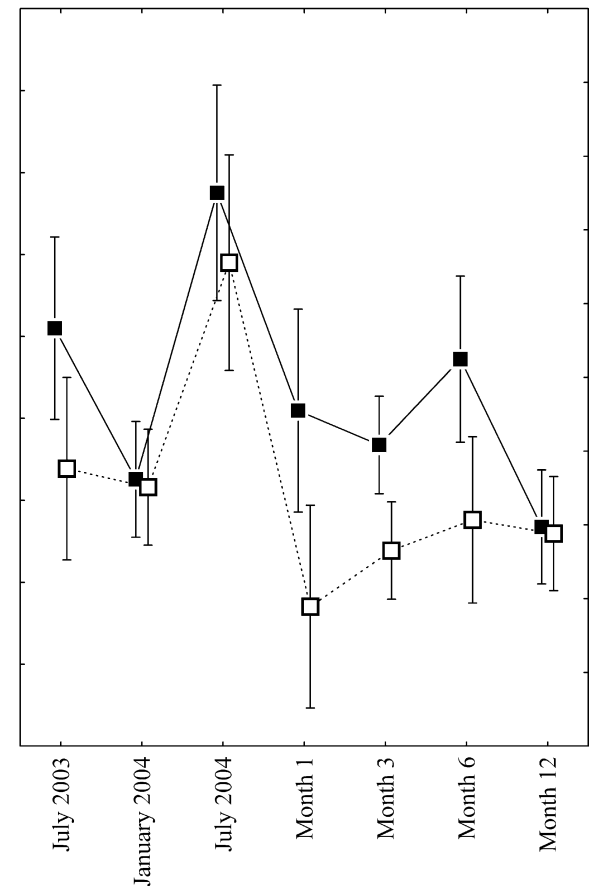

Debris Added

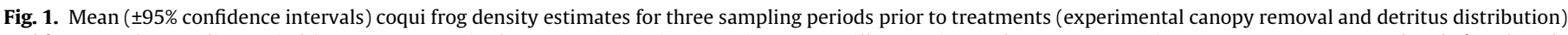

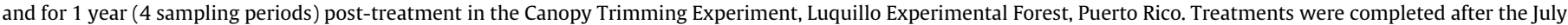

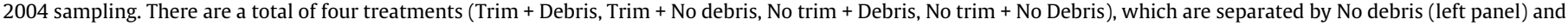
Debris added (right panel), and closed squares represent intact canopy plots, and open squares represent canopy trimmed plots.

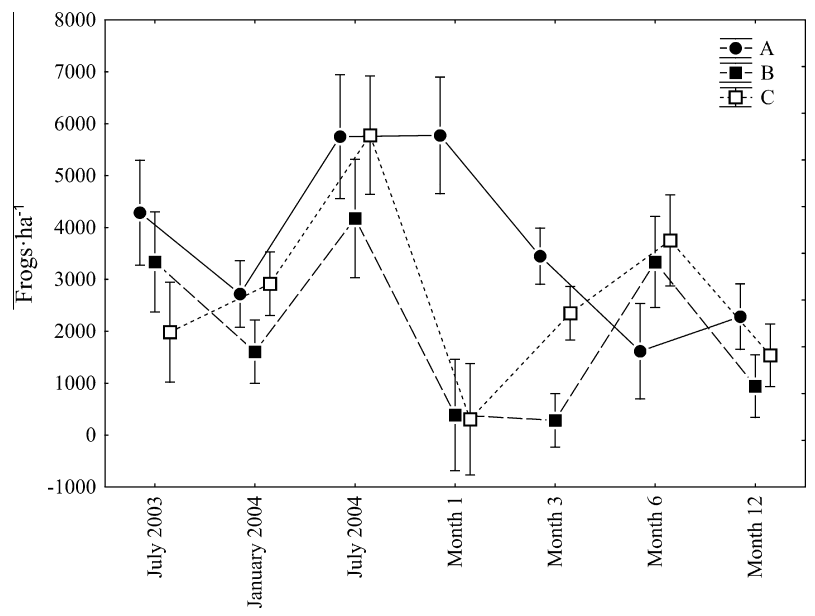

Fig. 2. Mean ( $\pm 95 \%$ confidence intervals) coqui frog density estimates for each of three blocks (A, B, and C) for three sampling periods prior to treatments (experimental canopy removal and detritus distribution) and for 1 year ( 4 sampling periods) post-treatment in the Canopy Trimming Experiment, Luquillo Experimental Forest, Puerto Rico. The temporally staggered effect of trimming blocks in sequence rather than simultaneously is shown. July represents wet season in Puerto Rico while January is considered the dry season. Treatments were completed after the July 2004 sampling (January-June 2005).

Debris, based on population increases reported by Woolbright $(1991,1996)$ in this same forest in Puerto Rico, and the positive relationship between the amount of understory habitat and coqui density found in wet forest in Hawaii (Beard et al., 2008). Surprisingly, we found that Trim treatments, irrespective of debris addition, resulted in a significant reduction in coqui densities during the first year following experimental hurricane treatments. A number of causal explanations could account for this unexpected result. The decline in coqui density in Trim plots could be the result of the lower litter moisture in Trim plots (12-15\% lower for first 4 months post-treatment, $6-8 \%$ for next 6 months) compared to intact canopy plots that were measured simultaneously with our coqui density estimates (Richardson et al., 2010). Fewer coquies have been previously associated with lower relative humidity in this forest (Drewry, 1970). Reduced litter moisture may have also been driving reductions in litter arthropod prey. Horn et al. (2005) concluded that the mechanistic cause for increased green tree frog populations was a correlated increase in insect abundance, yet Beard et al. (2008) in Hawaii did not find any significant relationship between coqui density and insect abundance. Because Richardson et al. (2010) reported that litter arthropod abundances declined in the CTE Trim plots and there was no effect of debris addition on litter arthropods, it could be that coqui populations were not responding to changes in litter moisture but were merely tracking arthropod prey fluctuations. Regardless of the mechanistic cause of coqui density declines, the conflicting results between the local scale responses by coqui in our experiment and the forest-scale coqui population studies conducted after actual hurricanes still remains.

The densities of coquies were lower in our study (c. 2500 frogs ha ${ }^{-1}$ ) for all treatments relative to previous studies in this forest (Stewart and Woolbright, 1996). We re-examined Woolbright's $(1991,1996)$ estimates of peak coqui densities 1 year after Hurricane Hugo and arrived at c. 3800-4300 frogs ha ${ }^{-1}$ (based on Fig. 1 of Woolbright, 1996). In addition, we extrapolated from Turner and Gist (1970) and Woolbright's $(1991,1996)$ prehurricane estimates of coqui and arrived at c. 2000 frogs ha $^{-1}$ and c. $4500-5000$ frogs ha $^{-1}$ (including c. $80 \%$ juveniles), respectively. Therefore, our density estimates are consistent with previous reports in the LEF. The wet season (June-December) tended to have greater densities of coqui in our study and that of previous mark-and-recapture studies in Puerto Rico (Turner and Gist, 1970; Woolbright, 1991, 1996; Fogarty and Vilella, 2002). Similarly, survival of coqui was also greater in the wet season than dry season in the LEF, regardless if sampling occurred following a severe hurricane (Woolbright, 1991). 
Woolbright (1996) reported a 6-fold increase in coqui density at 1 year after hurricane disturbance, and observed increased coqui density a mere 5 months after the formation of three tree fall gaps in a single plot. Some of the differences between our study and the work of Woolbright $(1991,1996)$ may be due to our treatment methodology and its relationship to conditions of a natural hurricane. While our $30 \times 30 \mathrm{~m}$ plots were similar in size to canopy disturbances following past severe hurricanes in the LEF (Brokaw and Grear, 1991; Shiels and González, 2014), these were the only plots disturbed in a comparatively undisturbed forest. However, the two-fold increase in canopy openness in Trim plots in our study returned to pre-hurricane conditions within about 16 months (Shiels and González, 2014), which was similar to that of this same forest after Hurricane Hugo in 1989 (14 months; Fernández and Fetcher, 1991). An additional difference between our treatment methodology and the conditions of a natural hurricane was that the length of time required to complete the canopy trimming allowed the litter to begin to decompose outside of the plots for an average of 75 days, a period in which two reproductive cycles of coqui could have occurred (Rivero, 1978). A pulse of offspring due to increased reproduction within the debris piles could have occurred outside of the $20 \times 20 \mathrm{~m}$ measurement areas and prior to the first sampling period. The canopy debris (woody debris cut into $\leqslant 1 \mathrm{~m}$ sections; Shiels and González, 2014) that was applied evenly to the surface of the plots was much more compressed than would have been after a natural hurricane or a single tree fall; thus our debris deposition treatments probably reduced forest floor complexity. The complex nature of the forest floor following natural hurricanes was suggested by Woolbright (1991, 1996) as a key factor contributing to the observed increases in coqui populations that result from hurricane disturbance in the LEF. Thus, it is possible that coqui populations respond differently to the amount and type of debris deposited onto the forest floor. It is unlikely that our detection methodology would have accounted for the lack of difference in coqui density associated with debris treatments because we used the same detection methodology (i.e., visual searching debris, vegetation, and other substrates) as Woolbright $(1991,1996)$ had used prior to and following Hurricane Hugo. While Hurricane Hugo resulted in large amounts of debris deposition (1.2-19 times annual litterfall; Lodge et al., 1991), which was largely due to the long period of low hurricane activity over the 57 years prior to its passing over the LEF, Hurricane Georges deposited smaller amounts of debris (0.55-0.93 times annual litterfall; Ostertag et al., 2003) and impacted the LEF merely 9 years after Hurricane Hugo. Additionally, litter mass on the forest floor was elevated for at least 1 year following Hurricane Hugo (Guzmán-Grajales and Walker, 1991) and during our experiment (Shiels et al., 2010), but litter mass had recovered to pre-disturbance status within 6 months after Hurricane Georges (Ostertag et al., 2003). The role of diminished forest floor complexity is supported by the findings of Vilella and Fogarty (2005) who found no significant increases in coqui population sizes after the passing of Hurricane Georges across their study site in the Cordillera Central (west of the LEF in Puerto Rico). Although the amount of debris deposited after Hurricane Hugo was similar to that deposited in our experimental debris deposition plots (Shiels et al., 2010), it appears there was less structural complexity in the understory in our study that did not benefit coqui populations.

\section{Conclusion}

While the results of our study differ from previous findings of coqui population dynamics following natural canopy disturbances, they are congruent with prior amphibian studies conducted at other sites following natural and experimental canopy disturbances. Greenberg (2001) found no change in amphibian abundance after natural canopy openings due to Hurricane Opal's passage through the Southern Appalachian Mountains, and Vilella and Fogarty (2005) did not detect a significant change in coqui after Hurricane Georges. In most prior work examining either salamander or frog populations following natural or anthropogenic canopy openings, the researchers observed declines in amphibian abundance and the majority of these cited changes in microclimate as being the primary driver of the declines (see review in Section 1). While these past studies did not attempt to decouple the effects of detritus deposition from the effects of opening the canopy, our study clearly identifies the opening of the canopy and concomitant microclimatic and/or prey availability changes as the primary driver of a decline in coqui frog density rather than an increase in coqui density due to increased reproduction facilitated by increased detritus on the forest floor. In some previous research (Popescu et al., 2012), the presence of coarse woody debris did not affect the decline in amphibian populations caused by canopy opening. Given the continued ambiguity surrounding the factors that control tropical frog population dynamics after canopy disturbances, any activities that remove significant canopy should probably be viewed as having negative to neutral effects on the frog community up to the first year post-disturbance in 0.09 ha plots (this study), and $>2-10$ years in much larger (>100 ha) plots (Ernst et al., 2006; Adum et al., 2013). In addition, further experimental detritus manipulations after large-scale wind storms might shed clarifying light on the responses of frogs to these types of disturbances.

\section{Acknowledgements}

This research was funded by grants DEB-0218039 and DEB0620910 from the U.S. National Science Foundation to the Institute for Tropical Ecosystem Studies, University of Puerto Rico, and the International Institute for Tropical Forestry, USDA Forest Service, as part of the Luquillo Long-Term Ecological Research Program. We thank the many volunteers, Luquillo LTER researchers, and El Verde Field Station staff for helping to complete the labor-intensive treatments. We also thank Jeff Pacelli, Elizabeth Reese, and Michael Strickland for assisting with coqui measurements, and two anonymous reviewers for their helpful comments on an earlier version of the manuscript.

\section{References}

Adum, G.B., Eichhorn, M.P., Oduro, W., Ofori-Boateng, C., Rödel, M.-O., 2013. Twostage recovery of amphibian assemblages following selective logging of tropical forests. Con. Biol. 27, 354-363.

Angulo-Sandoval, P., Fernandez-Marin, H., Zimmerman, J.K., Aide, T.M., 2004 Changes in patterns of understory leaf phenology and herbivory following hurricane damage. Biotropica 36, 60-67.

Ash, A.N., 1988. Disappearance of salamanders from clearcut plots. J. Elisha Mitchell Sci. Soc. 104, 116-122.

Beard, K.H., Al-Chokhachy, R., Tuttle, N.C., 2008. Population density and growth rates of Eleutherodactylus coqui in Hawaii. J. Herpetol. 42, 626-636.

Brokaw, N.V.L., Grear, J.S., 1991. Forest structure before and after Hurricane Hugo at three elevations in the Luquillo Mountains, Puerto Rico. Biotropica 23, 386-392.

Burslem, D.F.R.P., Whitmore, T.C., Brown, G.C., 2000. Short-term effects of cyclone impact and long-term recovery of tropical rain forest on Kolombangara, Solomon Islands. J. Ecol. 88, 1063-1078.

Drewry, G., 1970. Factors affecting activity of rain forest frog populations as measured by electrical recording of sound pressure levels. In: Odum, H.T., Pigeon R.F. (Eds.), A tropical rain forest. A study of irradiation and ecology at El Verde, Puerto Rico, pp. E55-E68.

Ernst, R., Rödel, M.-O., 2005. Anthropogenically induced change of predictability in tropical anuran assemblages. Ecology 86, 3111-3118.

Ernst, R., Linsenmair, K.E., Rödel, M.-O., 2006. Diversity erosion beyond the species level: dramatic loss of functional diversity after selective logging in two tropical amphibian communities. Biol. Conservation 133, 143-155.

Everham III, E.M., Brokaw, N.V.L., 1996. Forest damage and recovery from catastrophic wind. Bot. Rev. 62, 113-185. 
Ewel, J.J., Whitmore, J.L., 1973. The ecological life zones of Puerto Rico and the Virgin Islands. U.S. Forest Service Research Paper. ITF-18. Institute of Tropical Forestry, Rio Piedras, Puerto Rico.

Fernández, D.S., Fetcher, N., 1991. Changes in light availability following Hurricane Hugo at three elevations in the Luquillo Experimental Forest of Puerto Rico. Biotropica 23, 393-399.

Fogarty, J.H., Vilella, F.J., 2002. Population dynamics of Eleutherodactylus coqui in Cordillera Forest Reserves of Puerto Rico. J. Herpetol. 36, 193-201.

Formanowicz Jr., D.R., Stewart, M.M., Townsend, K., Pugh, F.H., Brussard, P.F., 1983. Predation by giant crab spiders on the Puerto Rican frog Eleutherodactylus coqui. Herpetologica 37, 125-129.

Gardner, T.A., Barlow, J., Peres, C.A., 2007. Paradox, presumption and pitfalls in conservation biology: The importance of habitat change for amphibians and reptiles. Biol. Conservation 138, 166-179.

Greenberg, C.H., 2001. Response of reptile and amphibian communities to canopy gaps created by wind disturbance in the southern Appalachians. Forest Ecol. Manage. 148, 135-144.

Guzmán-Grajales, S.M., Walker, L.R., 1991. Differential seedling responses to litter after Hurricane Hugo in the Luquillo Experimental Forest, Puerto Rico. Biotropica 23, 407-413.

Harpole, D.N., Haas, C.A., 1999. Effects of seven silvicultural treatments on terrestrial salamanders. Forest Ecol. Manage. 114, 349-356.

Horn, S., Hanula, J.L., Ulyshen, M.D., 2005. Abundance of green tree frogs and insects on artificial canopy gaps in a bottomland hardwood forest. Am. Midl. Nat. 155, 321-326.

Krebs, C.J., 1999. Ecological Methodology, 2nd Ed. Addison-Welsey Educational Publishers Inc., Menlo Park, California.

Lodge, D.J., Scatena, F.N., Asbury, C.E., Sanchez, M.J., 1991. Fine litterfall and related nutrient inputs resulting from Hurricane Hugo in subtropical wet and lower montane rainforests of Puerto Rico. Biotropica 23, 336-342.

Lugo, A.E., Applefield, M., Pool, D.J., McDonald, R.B., 1983. The impact of Hurricane David on the forests of Dominica. Can. J. Forest Res. 13, 201-211.

Lugo, A.E., 2008. Visible and invisible effects of hurricanes on forest ecosystems: an international review. Austral Ecol. 33, 368-398.

Ostertag, R., Scatena, F.N., Silver, W.L., 2003. Forest floor decomposition following hurricane litter inputs in several Puerto Rican forests. Ecosystems 6, 261-273.

Petranka, J.L., Eldridge, M.E., Haley, K.E., 1993. Effects of timber harvesting on southern Appalachian salamanders. Conservation Biol. 7, 363-370.

Popescu, V.D., Patrick, D.A., Hunter Jr., M.L., Calhoun, A.J.K., 2012. The role of forest harvesting and subsequent vegetative regrowth in determining patterns of amphibian habitat use. Forest Ecol. Manage. 270, 163-174.

Pough, F.H., Smith, E.M., Rhodes, D.H., Collazo, A., 1987. The abundance of salamanders in forest stands with different histories of disturbance. Forest Ecol. Manage. 20, 1-9.

Reagan, D.P., 1996. Anoline lizards. In: Reagan, D.P., Waide, R.B. (Eds.), The Food Web of a Tropical Rain Forest. University of Chicago Press, Chicago, pp. 321 345.
Richardson, B.A., Richardson, M.J., González, G., Shiels, A.B., Srivastava, D.S., 2010. A canopy trimming experiment in Puerto Rico: the response of litter invertebrate communities to canopy loss and debris deposition in a tropical forest subject to hurricanes. Ecosystems 13, 286-301.

Rivero, J.A., 1978. Los Anfibios y Reptiles de Puerto Rico. University of Puerto Rico Press, Rio Piedras.

Scatena, F.N., Larsen, M.C., 1991. Physical aspects of Hurricane Hugo in Puerto Rico. Biotropica 23, 317-323.

Shiels, A.B., Zimmerman, J.K., Garcia-Montiel, D.C., Jonckheere, I., Holm, J., Horton, D., Brokaw, N., 2010. Plant responses to simulated hurricane impacts in a subtropical wet forest, Puerto Rico. J. Ecol. 98, 659-673.

Shiels, A.B., González, G. 2014. Understanding the key mechanisms of tropical forest responses to canopy loss and biomass deposition from experimental hurricane effects. Forest Ecol. Manage. 332, 1-10.

StatSoft Inc, 2011. Statistica (data analysis software system), version 10 . <www.statsoft.com>.

Stewart, M.M., Pough, F.H., 1983. Population density of tropical forest frogs: Relation to retreat sites. Science 221, 570-572.

Stewart, M.M., Woolbright, L.L., 1996. Amphibians. In: Reagan, D.P., Waide, R.B. (Eds.), The Food Web of a Tropical Rain Forest. University of Chicago Press, Chicago, pp. 273-320.

Turner, F.B., Gist, C.S., 1970. Observations of lizards and tree frogs in an irradiated Puerto Rican forest. In: Odum, H.T., Pigeon R. F. (Eds.), A tropical rain forest. A study of irradiation and ecology at El Verde, Puerto Rico. E25-E49.

Turton, S.M., 1992. Understory light environments in a north-east Australian rain forest before and after a tropical cyclone. J. Trop. Ecol. 8, 241-252.

Vilella, F.J., Fogarty, J.H., 2005. Diversity and abundance of forest frogs (Anura: Leptodactylidae) before and after Hurricane Georges in Cordilla Central of Puerto Rico. Caribbean J. Sci. 41, 157-162.

Waide, R.B., 1991. Summary of the response of animal populations to hurricanes in the Caribbean. Biotropica 23, 508-512.

Waide, R.B., Reagan, D.P., 1996. The rain forest setting. In: Reagan, D.P., Waide, R.B. (Eds.), The Food Web of a Tropical Rain Forest. University of Chicago Press, Chicago, pp. 1-16.

Whitmore, T.C., Burslem, D.F.R.P., 1998. Major disturbances in tropical rainforests. In: Newberry, D.M., Prins, H.H.T., Brown, N.D. (Eds.), Dynamics of Tropical Communities. Blackwell Science, Oxford, pp. 549-565.

Woolbright, L.L., 1985. Patterns of nocturnal movement and calling by the tropical frog Eleutherodactylus coqui. Herpetologica 41, 1-9.

Woolbright, L.L., 1991. The impact of hurricane Hugo on forest frogs in Puerto Rico. Biotropica 23, 462-467.

Woolbright, L.L., 1996. Disturbance influences long-term population patterns in the Puerto Rican frog, Eleutherodactylus coqui (Anura: Leptodactylidae). Biotropica 28, 493-501.

Zimmerman, J.K., Wright, S.J., Calderón, O., Aponte Pagon, M., Patron, S., 2007. Flowering and fruiting phenologies of seasonal and aseasonal neotropical forests: the role of annual changes in irradiance. J. Trop. Ecol. 23, 231-251. 